\title{
АНАЛИЗ РАЗВИТИЯ КАДРОВОГО ПОТЕНЦИАЛА ОПК (НА ПРИМЕРЕ АЭРОКОСМИЧЕСКОЙ ПРОМЫШЛЕННОСТИ США)
}

\author{
Макарова Ю.А.
}

В статье рассмотрены проблемы развития карового потенщиала ОПК, а также проведено моделирование численности занятых высококвалифицированных специалистов с учетом макроэкономических показателей (на примере аэрокосмической промышленности США).

DOI: $10.20537 /$ mce2019econ14

Введение. Значительное сокращение финансирования обороннопромышленного комплекса (ОПК) России в период 1990-х гг. привело к снижению численности занятых как в промышленном секторе ОПК, так и в его научных организациях. В результате отсутствия притока специалистов на предприятиях ОПК был нарушен процесс воспроизводства кадрового потенциала, увеличился средний возраст научноконструкторских и производственных кадров (см. подробно $[1,2])$.

В настоящее время особое внимание уделяется исследованию проблем обеспечения ОПК научными и инженерно-техническими специалистами как в России, так и за рубежом (см, например, [3-6]). В частности, в зарубежных работах (см., например, [5]) отмечается старение кадрового состава, увеличение доли занятых научных и инженерных кадров в НИОКР гражданского назначения относительно их доли в аэрокосмической и оборонной промышленности наиболее развитых стран. Возможные способы решения кадровых проблем в ОПК России рассмотрены в работах [4,7-9].

В статье рассмотрена проблемы развития кадрового потенциала ОПК, а также проведена оценка численности занятых высококвалифицированных специалистов с учетом макроэкономических показателей на примере аэрокосмической промышленности США.

Проблемы развития кадрового потенциала ОПК. Кадровые проблемы в ОПК характерны как для России, так и для наиболее развитых стран. 
Например, в аэрокосмической и оборонной промышленности США и ОПК России требуется решение таких проблем, как старение кадрового состава, высокая потребность в высококвалифицированных специалистах, а также сложность подбора специалистов под заданные квалификационные требования предприятий и организаций ОПК $[5,10]$.

В США снижение численности высококвалифицированных специалистов в аэрокосмической оборонной промышленности, по оценкам [5], обусловлено их оттоком в другие сектора экономики. По данным 2016 г. около $31 \%$ от численности добровольно уволенных работников аэрокосмической промышленности в возрасте до 35 лет продолжили работать по специальности или избрали смежную, при этом 25\% перешли на специальность в другой сфере деятельности, а 19\% покинули отрасль (для прочих 25\% данные отсутствуют) [5].

Несмотря на более высокий средний уровень заработной платы инженеров в аэрокосмической промышленности США, чем у многих специалистов, например, финансового сектора, молодые высококвалифицированные специалисты склонны выбирать сферу деятельности с более привлекательными условиями для профессионального развития, поскольку в отраслях оборонной промышленности «отсутствует система мотивации для высококвалифицированных специалистов в отличие от гражданского сектора с большими возможностями» [6]. Большую долю среди добровольно уволенных работников аэрокосмической промышленности США составляют сотрудники со стажем работы до 5 лет $67.3 \%$ от общего числа увольнений в 2016 г., более половины из которых сотрудники инженерных специальностей. По оценкам [5], отток молодых высококвалифицированных специалистов из оборонной сферы в США происходит в результате их привлечения компаниями сферы информационных технологий гражданского сектора (например, Apple, Google и Amazon).

В России проблемы развития кадрового потенциала ОПК имеют свою специфику. В условиях увеличения численности занятых в отраслях ОПК на первый план выходят проблемы преодоления дефицита высококвалифицированных специалистов и «устранения накопленных структурных диспропорций» [11]. 
В 2018 г., по данным [10,12], средний возраст работников ОПК составлял около 45 лет, при этом, несмотря на рост доли работников в возрасте до 35 лет в общей численности занятых в ОПК (с 20\% в 2009 г. до $30 \%$ в 2018 г.), сохранился дефицит работников в возрасте от 35 до 45 лет. Более того, по данным [13], доля занятых научных и инженерных кадров в ОПК составляет около $22 \%$, при доле руководящего состава, равной $15 \%$, и рабочих - $63 \%$.

В настоящее время высококвалифицированные молодые специалисты не стремятся работать в ОПК. Основными причинами слабого притока молодых специалистов в ОПК, по мнению [14], являются «низкая заработная плата, при высоких требованиях к квалификации». Так, доля выпускников ВУЗов, трудоустроенных по специальности на предприятиях ОПК, составляет около $36 \%$, при этом доля выпускников аэрокосмических специальностей - не более 20\% [2]. По данным [15], около половины выпускников после приема на работу направляется на профессиональную переподготовку и повышение квалификации.

По оценкам [11], потребность в специалистах со среднетехническим и высшим образованием возрастает. В период до 2025 г. кадровая потребность ОПК по отраслям, подведомственным Министерству промышленности и торговли России, составит более 676 тыс. человек, в том числе: инженеров - 166 тыс. человек (рост на 28.0\% относительно 2016 г.); среднетехнического персонала — более 121 тыс. человек (на $19.0 \%$ ); рабочих - более 390 тыс. человек (на 53.0\%).

Таким образом, решение кадровых проблем в ОПК России должно включать не только подготовку высококвалифицированных кадров по профильным специальностям, но и стимулирование их притока и закрепления в отраслях ОПК [10].

Оценка численности занятых высококвалифицированных специалистов с учетом макроэкономических показателей на примере аэрокосмической промышленности США. Ввиду отсутствия достаточной статистической базы данных по России, для выявления факторов, оказывающих влияние на приток высококвалифицированных специалистов в отраслях ОПК, анализ проведен на примере аэрокосмической промышленности США* . Выбор для исследования данной отрасли

* В аэрокосмическую промышленность в соответствии с определением Aerospace Industries Association (AIA), включено также производство систем слежения, обнаруже- 
обусловлен высокой долей высококвалифицированных кадров в общей численности занятых.

С учетом различий в методологиях учета отдельных подгрупп, составляющих профессиональную группу инженеров, техников и инженерно-технических специалистов, в статье оценка проведена на примере занятых научных и инженерных кадров («science and engineering workers») в соответствии с классификацией, приводимой Национальным научным фондом CША (NSF) [16]. Численность занятых научных и инженерных кадров суммировались по следующим кодам Системы стандартной классификации профессий $(\mathrm{SOC})^{*}$ : профессии в сфере математики и вычислительной техники (15-0000), архитектурные и инженерные профессии (17-0000), профессии в биологических, физических и общественных науках (19-0000) за исключением технических работников (17-3000 и 19-4000) на основе данных [17].

В 2002-2014 гг. в аэрокосмической промышленности США наблюдался рост численности научных и инженерных кадров, несмотря на значительное сокращение в период финансово-экономического кризиса 2008 г. (см. табл.1). В 2014 г. численность научных и инженерных кадров, по данным [18], составляла 103.3 тыс. человек или $21.02 \%$ от общей численности занятых в отрасли.

Динамика используемых основных макроэкономических показателей приведена в табл. 1.

Оценивались параметры регрессионных моделей следующего вида:

$$
\ln y=\sum_{i=1}^{5} a_{i} \ln x_{i, t-j_{i}}+b+\sum_{k=1}^{2} c_{k} D_{k},
$$

где $y$ - численность занятых научных и инженерных кадров в аэрокосмической промышленности США; в качестве факторов $(i=1, \ldots, 5)$ использовались расходы на высшее образование ( $x_{1}$, по данным [18]), расходы на объекты капитального строительства и оборудование в отрасли $\left(x_{2}\right.$, по данным [20]); доля расходов на оборону в ВВП ( $x_{3}$, по данным [19]); расходы на НИОКР в отрасли ( $x_{4}$, по данным [21]) и их доля в общих расходах на НИОКР в промышленности ( $x_{5}$, по данным [21]); $D_{k}-$ фиктивные

ния и навигации (NAICS 334511). В связи с отсутствием данных о численности занятых в данной подотрасли, она не вошла в исследование.

* Система, используемая федеральными статистическими учреждениями для классификации работников по категориям; все работающее население подразделяется на 820 профессий, которые разбиты на 96 групп. 
переменные $\left(\mathrm{D}_{1}=1\right.$ в период 2009-2011 гг. и 0 для остальных лет отражают сокращение численности высококвалифицированных работников в результате кризисных процессов в экономике; $\mathrm{D}_{2}=1$ в 2013 г. и 0 для остальных лет отражает изменение профессиональноквалификационной структуры в Системе стандартной классификации профессий). Введение в модель лаговых переменных позволяет учесть факторы, влияющие на предложение труда молодых специалистов, а также на динамику формирования потребности в научных и инженерных кадрах в отрасли [9,22].

Таблица 1. Динамика численности занятых научных и инженерных кадров в аэрокосмической промышленности и основных макроэкономических показателей США в 2002-2014 гг. (индекс, 2002 г. =1).

\begin{tabular}{|l|l|l|l|l|l|}
\hline Показатели & 2002 & 2005 & 2008 & 2010 & 2014 \\
\hline $\begin{array}{l}\text { Численность научных и инженерных кад- } \\
\text { ров аэрокосмической промышленности }\end{array}$ & 1 & 1.06 & 1.07 & 1.06 & 1.11 \\
\hline Расходы на высшее образование & 1 & 1.06 & 1.04 & 1.17 & $\ldots$ \\
\hline $\begin{array}{l}\text { Расходы на объекты капитального } \\
\text { строительства и оборудование в отрасли }\end{array}$ & 1 & 1.32 & 1.70 & 1.28 & 1.81 \\
\hline Расходы на НИОКР в отрасли & 1 & 1.44 & 2.44 & 2.46 & $\ldots$ \\
\hline $\begin{array}{l}\text { Доля расходов на НИОКР отрасли в \% } \\
\text { от общих в промышленности }\end{array}$ & 1 & 1.31 & 1.87 & 2.11 & $\ldots$ \\
\hline Доля расходов на оборону в ВВП & 1 & 1.31 & 1.43 & 1.58 & 1.19 \\
\hline
\end{tabular}

Результаты оценки численности занятых научных и инженерных кадров в аэрокосмической промышленности США для временной выборки 2002-2014 гг. приведены в табл. 2.

Полученные результаты подтверждают, что росту численности занятых научных и инженерных кадров способствует увеличение государственных расходов на высшее образование и затрат на оборону. Также получена положительная корреляция численности занятых научных и инженерных кадров с расходами на объекты капитального строительства и оборудование в аэрокосмической промышленности США и расходами на НИОКР в отрасли. Для численности занятых научных и инженерных кадров эластичность прироста расходов на объекты капитального строительства и оборудование аэрокосмической промышленности США составляла от 0.06 до $0.11 \%$, а расходов на НИОКР в отрасли $-0.03 \%$. 
Таблица 2. Результаты моделирования численности занятых научных и инженерных кадров в аэрокосмической промышленности США.

\begin{tabular}{|c|c|c|c|c|c|}
\hline Регрессоры & $\begin{array}{c}\text { Модель } \\
1\end{array}$ & $\begin{array}{c}\text { Модель } \\
2\end{array}$ & $\begin{array}{c}\text { Модель } \\
\mathbf{3} \\
\end{array}$ & $\begin{array}{c}\text { Модель } \\
4\end{array}$ & $\begin{array}{c}\text { Модель } \\
5\end{array}$ \\
\hline Константа & $\begin{array}{c}3.26 \\
(11.1)\end{array}$ & $\begin{array}{c}3.89 \\
(31.85)\end{array}$ & $\begin{array}{c}3.02 \\
(13.5)\end{array}$ & $\begin{array}{c}3.81 \\
(21.73)\end{array}$ & $\begin{array}{c}3.54 \\
(18.35)\end{array}$ \\
\hline $\begin{array}{l}\text { Расходы на высшее об- } \\
\text { разование }\left(\mathrm{x}_{1, \mathrm{t}-3}\right)\end{array}$ & $\begin{array}{c}0.22 \\
(3.01)\end{array}$ & & $\begin{array}{c}0.24 \\
(4.07)\end{array}$ & & $\begin{array}{c}0.13 \\
(2.25)\end{array}$ \\
\hline $\begin{array}{l}\text { Расходы на объекты ка- } \\
\text { питального строительст- } \\
\text { ва и оборудование в от- } \\
\text { расли }\left(\mathrm{x}_{2, \mathrm{t}-1}\right)\end{array}$ & $\begin{array}{c}0.06 \\
(2.03)\end{array}$ & $\begin{array}{l}0.11 \\
(3.7)\end{array}$ & & & \\
\hline $\begin{array}{l}\text { Доля расходов на обо- } \\
\text { рону в ВВП }\left(\mathrm{x}_{3, t-4)}\right.\end{array}$ & & & $\begin{array}{c}0.09 \\
(3.48) \\
\end{array}$ & $\begin{array}{c}0.13 \\
(2.73) \\
\end{array}$ & \\
\hline $\begin{array}{l}\text { Расходы на НИОКР в } \\
\text { отрасли }\left(\mathrm{x}_{4, \mathrm{t}-1}\right)\end{array}$ & & $\begin{array}{c}0.03 \\
(1.02)\end{array}$ & & $\begin{array}{c}0.03 \\
(0.96) \\
\end{array}$ & \\
\hline $\begin{array}{l}\text { Доля расходов на } \\
\text { НИОКР отрасли в\% от } \\
\text { общих в промышленно- } \\
\text { сти }\left(\mathrm{x}_{5, \mathrm{t}-1}\right) \\
\end{array}$ & & & & & $\begin{array}{c}0.09 \\
(4.35)\end{array}$ \\
\hline (n) & $\begin{array}{l}-0.02 \\
(1.45)\end{array}$ & $\begin{array}{l}-0.03 \\
(-1.7) \\
\end{array}$ & $\begin{array}{l}-0.04 \\
(-2.61)\end{array}$ & $\begin{array}{l}-0.05 \\
(-2.08)\end{array}$ & $\begin{array}{l}-0.06 \\
(-4.64)\end{array}$ \\
\hline $\mathrm{D}_{2}$ & $\begin{array}{c}0.03 \\
(1.45)\end{array}$ & $\begin{array}{c}0.04 \\
(1.92)\end{array}$ & $\begin{array}{c}0.01 \\
(0.52)\end{array}$ & $\begin{array}{c}0.03 \\
(1.22)\end{array}$ & $\begin{array}{c}0.04 \\
(3.38)\end{array}$ \\
\hline $\mathrm{R}^{2}$ & 0.808 & 0.849 & 0.909 & 0.75 & 0.948 \\
\hline
\end{tabular}

Выводы. Анализ, проведенный на примере аэрокосмической промышленности США, показал, что на увеличение численности занятых научных и инженерных кадров в отраслях ОПК значительное влияние оказывает увеличение государственных расходов на оборону и высшее образование. При этом росту численности научных и инженерных кадров в отраслях ОПК способствует увеличение отраслевых расходов на объекты капитального строительства и оборудование, а также отраслевых расходов на НИОКР. 


\section{СПИСОК ЛИТЕРАТУРЫ}

1. Макарова Ю.А. Проблемы обеспечения обороноспособности России // Анализ и моделирование экономических и социальных процессов / Математика. Компьютер. Образование: Сб. научн. трудов (выпуск 21). № 2. М.-Ижевск: НИЦ «Регулярная и хаотическая динамика», 2014. с.102-109.

2. Виноградов Б.А., Пальмов В.Г. Развитие кадрового потенциала обороннопромышленного комплекса. - СПб.: Наука, 2013.

3. Чумадин А., Ершов В. Подготовка кадров для аэрокосмической промышленности: проблемы стандартов // Высшее образование в России. 2006. № 7. c. 65-69.

4. Иванов С.В., Подольский А.Г. Обеспечение кадрами организаций оборонно-промышленного комплекса: постановка задачи и методический подход к ее решению // Известия Российской академии ракетных и артиллерийских наук. 2017. № 4 (94). с 44-51.

5. Aerospace Industries Association. URL: http://www.aia-aerospace.org/

6. Center for Aviation and Aerospace Leadership. URL: http://worldwide.erau.edu/caal/

7. Никонова М.А. Кластерный анализ результативности в сфере НИОКР // Научно-практический журнал «Конщепџии». 2013. №2(31). с. 67-72.

8. Варшавский Л.Е., Дубинина М.Г., Петрова И.Л. Проблемы развития кадровой составляющей научного потенциала в России и за рубежом // Научнопрактический журнал «Конщепщии». 2007. № 1 (18). с. 12-26.

9. Кочеткова E.B. Моделирование потребности в инженерно-технических специалистах для наукоемких отраслей (на примере аэрокосмической промышленности США) // Научно-практический журнал «Конщепчии». 2018. № 1 (37). с. 64-71.

10. Развитие кадрового потенциала оборонно-промышленного комплекса и Вооруженных Сил Российской Федерации / Б. А. Виноградов, В. Г. Пальмов. - СПб: Изд-во Политехн. ун-та, 2015.

11. ФГУП «ЦНИИ «Центр». URL: http://www.cniicentr.ru/index.php/ru/

12. Оборонно-промышленный комплекс. Государственный оборонный заказ: некоторые факты за 6 лет / Сайт Правительства РФ.

URL: http://government.ru/info/32164/

13. Ильницкий А., Лосев А. Прорыв «двойного назначения»// «Газета.Ру» . 27.06.2017. URL: https://www.gazeta.ru/comments/2017/06/26_a_10738907.shtml\#page14

14. Розина Н.M. О разработке нового поколения образовательных стандартов // Высшее образование в России. 2007. №3. с.3-9. 
15. Капралов Г.Н. Нужны согласованность и оперативность // Экспертный союз, № 6. URL: http://www.unionexpert.ru/index.php/news/item/437-we-need-consistency-and-efficiency

16. National Science Board. Science \& Engineering Indicators 2018.

URL: https://www.nsf.gov/statistics/2018/nsb20181/assets/901/science-and-engineeringlabor-force.pdf

17. Bureau of Labor Statistics. URL: https://www.bls.gov/

18. The World Bank. URL: https://www.worldbank.org/

19. Stockholm international peace research institute (SIPRI). URL: https://www.sipri.org/

20. Economic Census. URL: https://www.census.gov/

21. The National Science Foundation.URL:https://www.nsf.gov/

22. Подольский А.Г., Косенко А.А., Иванов С.В. Оптимизация кадрового обеспечения организаций оборонно-промышленного комплекса на макро- и микроуровне // Вооружение и экономика. 2018. №1 (43). с. 80-90.

\section{ANALYSIS OF HUMAN CAPITAL DEVELOPMENT IN THE DEFENSE INDUSTRIAL COMPLEX (ON THE EXAMPLE OF THE US AEROSPACE INDUSTRY)}

\section{Makarova Yu.A.}

In the article the analysis of the problem of science and engineering specialists shortage in the defense industrial complex is given as far as modeling of the number of highly qualified specialists employed in defense industries concerning macroeconomic indicators was conducted. 